\begin{tabular}{c|c|c}
\hline \hline $\begin{array}{c}\text { Vol. 32(3):321-329 } \\
\text { DOI: } 10.4217 / O P R .2010 .32 .3 .321\end{array}$ & Ocean and Polar Research & September 2010 \\
\hline \hline
\end{tabular}

\title{
Article
}

\section{Temporal Variation of Phytoplankton Community Related to Water Column Structure in the Korea Strait}

\author{
Yong-Woo Lee', Hyun Je Park², Eun Jung Choy ${ }^{3}$, Yunsook Kim², and Chang-Keun Kang²* \\ ${ }^{1}$ Department of Oceanography \\ Pusan National University, Busan 609-735, Korea \\ ${ }^{2}$ Ocean Science and Technology Institute \\ Pohang University of Science and Technology, Pohang 790-784, Korea \\ ${ }^{3}$ Korea Polar Research Institute, KORDI \\ Incheon 406-840, Korea
}

\begin{abstract}
Photosynthetic pigments, nutrients, and hydrographic variables were examined in order to elucidate the spatio-temporal variation of water column structure and its effect on phytoplankton community structure in the western channel of the Korea Strait in fall 2006 and spring 2007. High phytoplankton biomass in the spring was associated with high salinity, implying that nutrients were not supplied by coastal waters or the Yangtze-River Diluted water (YRDW) with low salinity. Expansion of the Korea Strait Bottom Cold Water (KSBCW) and a cold eddy observed during the spring season might enhance the nutrient supply from the subsurface layer to the euphotic zone. Chemotaxonomic examination showed that diatoms accounted for $60-70 \%$ of total biomass, followed by dinoflagellates. Nutrient supply by physical phenomena such as the expansion of the KSBCW and the occurrence of a cold eddy appears to be the controlling factors of phytoplankton community composition in the Korea Strait. Further study is needed to elucidate the mechanisms by which the $\mathrm{KSBCW}$ is expanded, and its role in phytoplankton dynamics.
\end{abstract}

Key words : phytoplankton, nutrients, Korea Strait, Korea Strait Bottom Cold Water, eddy

\section{Introduction}

Phytoplankton community structure in the ocean may have an effect on biological productivity, food web structure in pelagic and benthic ecosystems, and carbon export to the deep ocean (Azam et al. 1983; Karl 1999; Karl et al. 2001). Phytoplankton community composition and biomass are controlled by various physical and chemical factors including nutrient and light conditions, seawater acidification, and hydrographic features such as water column structure, eddies, and upwelling (Schofield et al. 1993; Ruardij et al. 1997; Moline 1998; Lee et al. 2009).

The Korea Strait is located between the Korean

\footnotetext{
*Corresponding author. E-mail : ckkang@postech.ac.kr
}

peninsula and the Japanese islands. It is similar to a sill separating the East China Sea (ECS) and the East/Japan Sea (EJS). The Tsushima Warm Current (TWC), a branch of the Kuroshio Warm Current (KWC), is the principal surface current flowing northeastward from the ECS into the EJS through the Korea Strait. It plays an important role in transporting nutrients and various materials, originating from Yangtze-River discharge, to the southern region of the EJS and the Korea Strait (Yanagi 2002; Onitsuka et al. 2007; Morimoto et al. 2009).

The Korea Strait is a dynamic environment because of topography, river discharge (e.g. Yangtze River), and current transport. Having the largest flux of freshwater and various materials into the ECS, annual discharge from the Yangtze River was reported to be approximately $9.25 \times 10^{11} \mathrm{~m}^{3} \mathrm{yr}^{-1}$ (Tian et al. 1993). Freshwater discharge 
control by the recent construction of the Three Gorges Dam on the Yangtze River (Jiao et al. 2007) was suggested to influence physical and chemical environments as well as biological response in the ECS, Korea Strait, and potentially EJS (Liu et al. 2003; Gong et al. 2006; Onitsuka et al. 2007; Jiao et al. 2007). Yang et al. (2000) suggested that initiation of the harmful algal bloom occurring along the southern coast of Korea during summer season is related to the intrusion of the YangtzeRiver Diluted water (YRDW) containing high nutrients. Volume transport of the TWC through the Korea Strait exhibits a seasonal variation, typically high in the summer and low in the winter (Lyu et al. 2002; Takikawa et al. 2005). Counterclockwise eddies, affecting phytoplankton biomass in the euphotic zone, have been observed frequently in the eastern channel of the Korea Strait (Morimoto et al. 2009).

It is important to understand the relationship between phytoplankton community structure and the hydrological and chemical variables in a complex system like the Korea Strait (Onitsuka et al. 2009). However, few studies have been conducted to understand temporal variation of phytoplankton community structure and biomass, and the relationship to short- and long-term variability in water mass properties in the Korea Strait.

To understand the biological change (phytoplankton community structure) related to temporal variation of physical and chemical environments in the Korea Strait, this study investigated 1) the spatial and temporal variation of water mass properties, including nutrient dynamics, and 2) the response of phytoplankton biomass and community structure to water mass variations in a northwest-southeast transect across the Korea Strait using HPLC pigment analysis and CHEMTAX analysis of pigment signatures, which have been used as powerful tools for studying phytoplankton community (Mackey et al. 1996; Hassen et al. 2008).

\section{Materials and methods}

\section{Study area and seawater sampling}

The Korea Strait is divided by Tsushima Island into eastern and western channels. This study was mainly conducted in the western channel of the Korea Strait. Hydrographic observation and seawater sampling were conducted on 9 October, 26 October, and 13 November in 2006 as well as 28 May in 2007 along a transect located in the western channel of Tsushima Island (St. NK1-NK6 in Fig. 1). In May 2007, the cruise was extended to the eastern channel of the Korea Strait (St. NK1-NK10). Hydrographic properties (temperature and salinity) were measured with a CTD profiler (Seabird Electronics 911).

\section{Nutrient and photosynthetic pigment analyses}

Water samples for nutrient and pigment analyses were taken at depth intervals of $10 \mathrm{~m}$ in the upper layer above $150 \mathrm{~m}$ at each station in the transect, with the exception of some stations. To determine nutrient concentration, approximately $500 \mathrm{ml}$ of each seawater sample was filtered through GF/F filters ( $25 \mathrm{~mm}$ in diameter) and

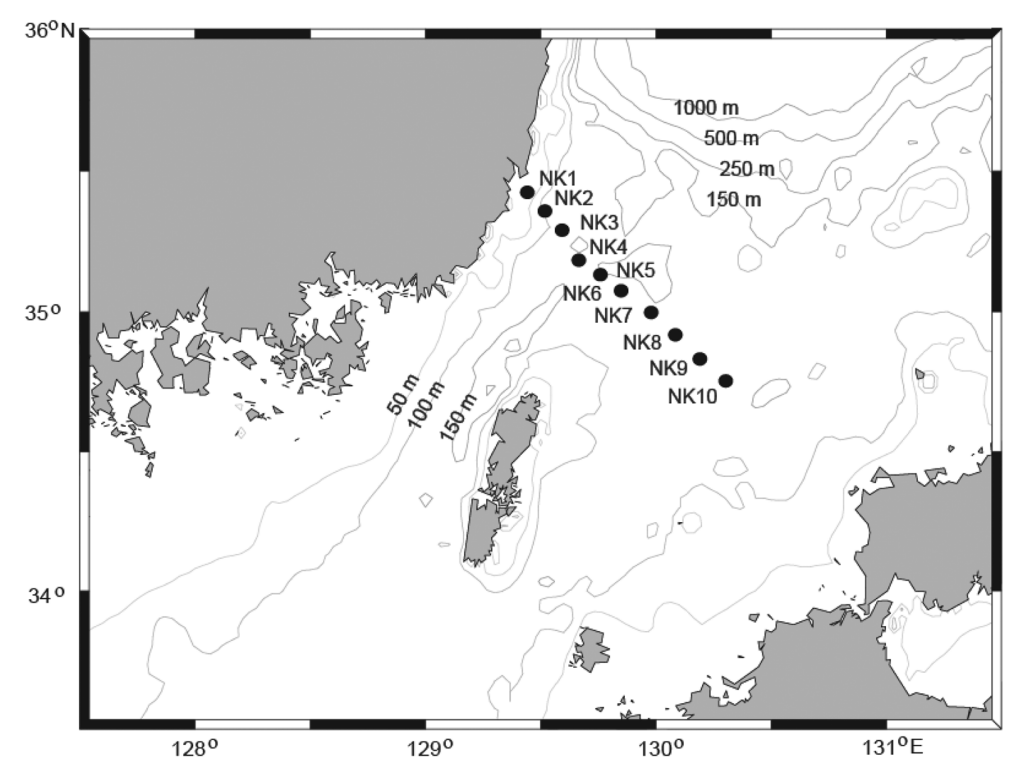

Fig. 1. Sampling locations in the Korea Strait. 
stored in a freezer at $-20^{\circ} \mathrm{C}$. Concentrations of $\mathrm{NO}_{3}{ }^{-}, \mathrm{NO}_{2}^{-}$, $\mathrm{PO}_{4}{ }^{3-}$, and $\mathrm{Si}(\mathrm{OH})_{4}$ were analyzed with an Auto-Analyzer (Futura plus II, Alliance Co.). $\mathrm{NO}_{\mathrm{x}}$ is defined as the sum of $\mathrm{NO}_{3}^{-}$and $\mathrm{NO}_{2}^{-}$, DIP as $\mathrm{PO}_{4}{ }^{3-}$, and DSi as $\mathrm{Si}(\mathrm{OH})_{4}$.

To analyze photosynthetic pigments, seawater samples $(\sim 21)$ were filtered immediately after sampling using GF/ F filters (47 $\mathrm{mm}$ in diameter) onboard the ship. Each filter was wrapped in aluminum foil and stored in a freezer $\left(-20^{\circ} \mathrm{C}\right)$. Upon arrival at the land-based laboratory, the samples were stored at $-80^{\circ} \mathrm{C}$ in a deep freezer until analysis. The samples were extracted with $100 \%$ acetone $(5 \mathrm{ml})$ for $24 \mathrm{hrs}$ in the dark $\left(-20^{\circ} \mathrm{C}\right)$ after sonication for 5 minutes to enhance cell disruption. The extracted solution was centrifuged at $2500 \mathrm{rpm}$ for $10 \mathrm{~min}$ to remove particulate materials. Supernatant $(1 \mathrm{ml})$ was well-mixed with $300 \mu \mathrm{l}$ of deionized water. Then $100 \mu \mathrm{l}$ of this mixture was analyzed by reverse-phase high-performance liquid chromatograph (Shimadzu Co. system) equipped with a Rexchrom-S5-100-ODS column (Regis, USA, $250 \times 4.6 \mathrm{~mm}$, particle size: $5 \mu \mathrm{m}$ ), following a modified method described by Wright et al. (1991). Canthaxanthin was used as an internal standard. Standard pigments were quantified by a spectrophotometer using a published extinction coefficient (Jeffrey 1997). Pure standard pigments, obtained from Sigma Chemical and DHI, were used to identify pigment peaks and calibrate pigment concentrations based on the peak areas.

On the basis of measured pigment signatures, phytoplankton community composition was determined using the CHEMTAX program (Mackey et al. 1996). In this study, the diagnostic biomarker pigments are chlorophyll $a$, fucoxanthin, 19'-hexanoyloxy-fucoxanthin, 19'-butanoyloxyfucoxanthin, peridinin, chlorophyll $b$, prasinoxanthin, lutein, violaxanthin, alloxanthin, and zeaxanthin. Modified from the values in Mackey et al. (1996), class-specific pigment ratios were used as the input pigment ratios of the CHEMTAX program (Table 1). The initial ratios of marker pigments to chlorophyll $a$ for chlorophytes, dinoflagellates, diatoms, and cyanobacteria were obtained from phytoplankton species isolated from offshore seawaters of the Korean peninsula by the Korea Marine Microalgae Culture Center (KMMCC).

\section{Results and discussion}

\section{Distributions of temperature, salinity, and nutrients}

Various factors, such as light intensity, stability of the water column, temperature, and nutrient concentrations, may influence biomass and community composition of phytoplankton (Reid et al. 1990; Lee et al. 2009). During the study periods, seawater temperature and salinity ranged from 5 to $25^{\circ} \mathrm{C}$ and from 32 to 35 , respectively. Temperature in May $2007\left(5-20^{\circ} \mathrm{C}\right)$ was lower than in October and November $2006\left(8-25^{\circ} \mathrm{C}\right)$, while salinity in May 2007 (33-34.5) was higher than in fall 2006 (32.234.5) (Fig. 2). Temperature and salinity in surface waters increased gradually from on the shelf to off the shelf, reflecting the increasing influence of $\mathrm{KWC}$ with high temperature and salinity (Fig. 3).

Expansion and contraction of the bottom cold water mass $\left(<10^{\circ} \mathrm{C}\right)$ in the Korea Strait varied seasonally (Fig. 3). In May 2007, the Korea Strait Bottom Cold Water (KSBCW) $\left(<10^{\circ} \mathrm{C}\right)$ expanded to off the shelf (St. NK6) and reached up to $20 \mathrm{~m}$ in depth below the surface mixed layer on the shelf (St. NK1). Presence of the KSBCW in the bottom layer of the Korea Strait and its seasonal variability has been reported (Lim and Chang 1969; Cho and Kim 1998). Lim and Chang (1969) suggested that the KSBCW originates from the western region of the EJS (the southeastern coast of the Korean peninsula) and

Table 1. Initial pigment ratios used for the CHEMTAX program. *Pigment ratios from our cultures

\begin{tabular}{clcccccccccc}
\hline & & Perid & But-fuco & Fuco & Hex-fuco & Pras & Viola & Allo & Lut & Zea & Chl $\boldsymbol{b}$ \\
\hline \multirow{6}{*}{$\begin{array}{c}\text { Initial } \\
\text { ratio }\end{array}$} & Prasino & 0 & 0 & 0 & 0 & 0.3151 & 0.0616 & 0 & 0.0088 & 0 & 0.9452 \\
& Dino* & 0.6547 & 0 & 0 & 0 & 0 & 0 & 0 & 0 & 0 & 0 \\
& Crypto & 0 & 0 & 0 & 0 & 0 & 0 & 0.2292 & 0 & 0 & 0 \\
& Prymne & 0 & 0 & 0 & 1.7059 & 0 & 0 & 0 & 0 & 0 & 0 \\
& Pelago & 0 & 0.2453 & 0.5849 & 0.5377 & 0 & 0 & 0 & 0 & 0 & 0 \\
& Chloro* & 0 & 0 & 0 & 0 & 0 & 0.0321 & 0 & 0.2379 & 0.0076 & 0.3361 \\
& Cyano* & 0 & 0 & 0 & 0 & 0 & 0 & 0 & 0 & 0.2808 & 0 \\
& Diatoms* & 0 & 0 & 0.5464 & 0 & 0 & 0 & 0 & 0 & 0 & 0 \\
\hline
\end{tabular}

${ }^{1}$ Abbreviations: Prasino, Prasinophytes; Dino, Dinoflagellates; Crypto, Cryptophytes; Prymne, Prymnesiophytes; Pelago, Pelagophytes; Chloro, Chlorophytes; Cyano, Cyanobacteria; Perid, Peridinin; But-fuco, 19'-butanoyloxy-fucoxanthin; Fuco, Fucoxanthin; Hex-fuco, 19'-hexanoyloxyfucoxanthin; Pras, Prasinoxanthin; Viola, Violaxanthin; Allo, Alloxanthin; Lut, Lutein; Zea, Zeaxanthin; and, Chl $b$, Chlorophyll $b$. 


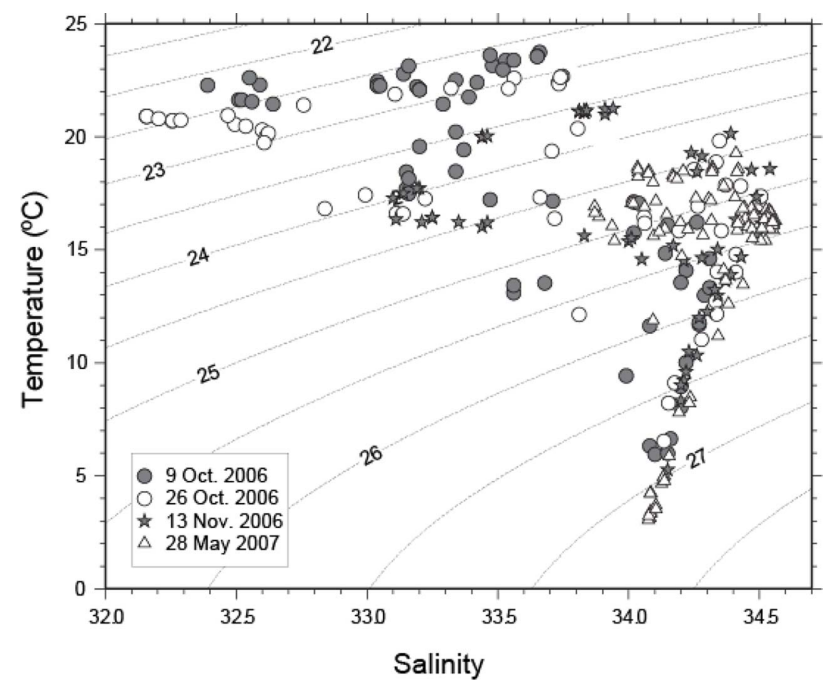

Fig. 2. T-S diagrams of the water column of the NK transect in the Korea Strait.

expands broadly in the summer compared to the winter season (Kim et al. 2006). The expansion and upwelling of the KSBCW on the shelf in May 2007 appears to have enhanced nutrient supply to the surface layer and, consequently, enhanced phytoplankton growth.

Surface mixed layer gradually increased offshore with increasing water depth. The surface mixed layer was 40$60 \mathrm{~m}$ thick and much shallower in November 2006 and May 2007 than in October 2006 (Fig. 3). Mixed layer depth is one of the main factors controlling the supply of nutrients from the subsurface layer to the euphotic zone, triggering phytoplankton growth. Chen and Chen (2006) reported that phytoplankton biomass was higher in the winter when surface mixed layer was shallow than in the summer. A shallow surface mixed layer formed on the shelf in May 2007, especially, because of a strong KSBCW.

A more expanded region was examined to include the off shelf region (St. NK7-NK10) in May 2007. A cold eddy associated with the shallow surface mixed layer near Tsushima island station was observed in May 2007. Counterclockwise eddies in the Korea Strait have been observed frequently (Takikawa et al. 2005; Morimoto et al. 2009). This island-induced eddy has a significant impact on the nutrient supply from the subsurface layer to the euphotic zone, enhancing primary production (Morimoto et al. 2009; Onitsuka et al. 2009).

The concentration of dissolved inorganic nitrogen $\left(\mathrm{NO}_{\mathrm{x}}: \mathrm{NO}_{3}^{-}+\mathrm{NO}_{2}^{-}\right)$in the surface seawater $(0-20 \mathrm{~m})$ was mostly less than $2 \mu \mathrm{M}$ (Fig. 4). In the euphotic zone ( $<40 \mathrm{~m}$ depth: approximately $1 \%$ of the surface light penetration), concentrations of dissolved inorganic phosphate (DIP) and silicate (DSi) were in the range of 0.0-1.50 and 0.19$36.9 \mu \mathrm{M}$, respectively. The nutrient $\left(\mathrm{NO}_{\mathrm{x}}, \mathrm{DIP}\right.$, and $\left.\mathrm{DSi}\right)$ concentrations in the euphotic zone were higher in late fall (13 November 2006), when water column stratification was weakened, than in October 2006. In May 2007, although water column stratification was weakened, nutrient concentrations in the euphotic zone were low. Nutrient concentrations are mainly controlled by river discharge, water column stratification, and atmospheric deposition. Many studies have reported that excess nutrients in the Korea Strait are supplied by the YRDW (Onitsuka et al. 2007; Morimoto et al. 2009). High precipitation in summer influences salinity and chemical characteristics in the Korea Strait. Salinity in fall 2006

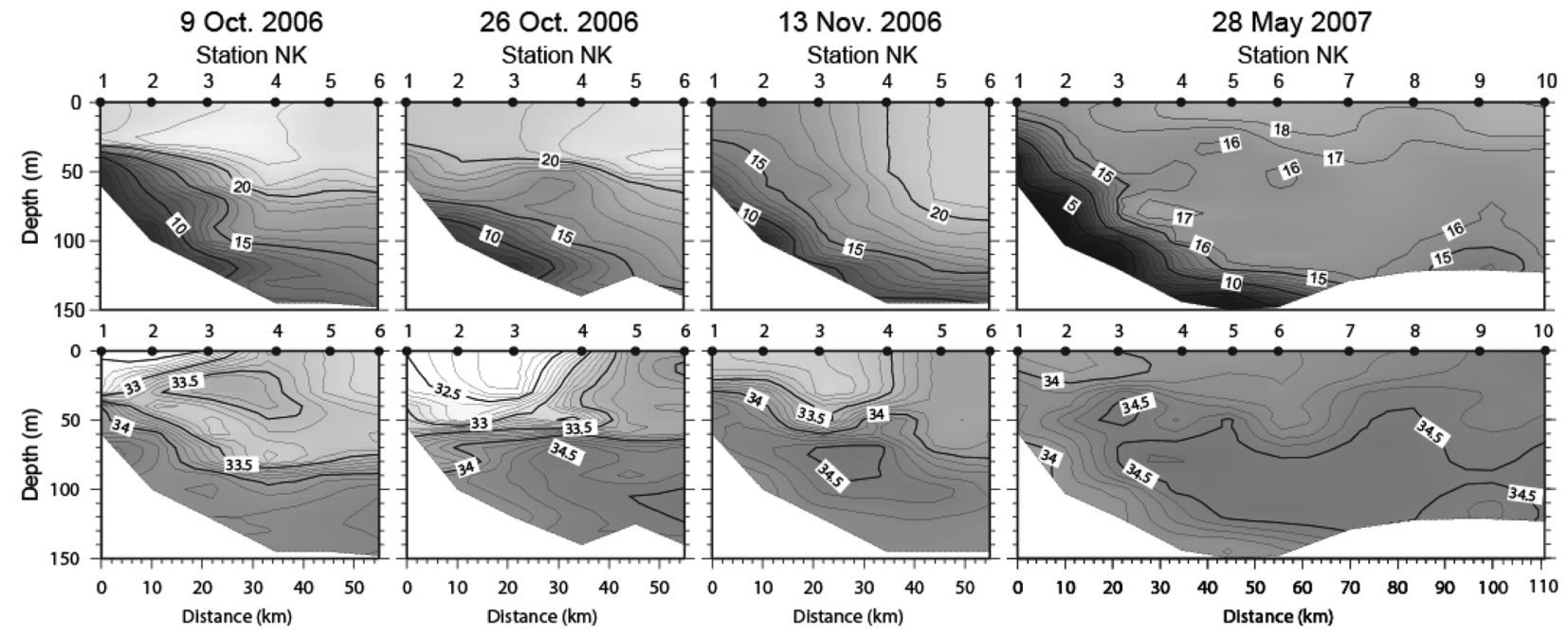

Fig. 3. Contour plots of temperature and salinity along the NK transect in the Korea Strait. 


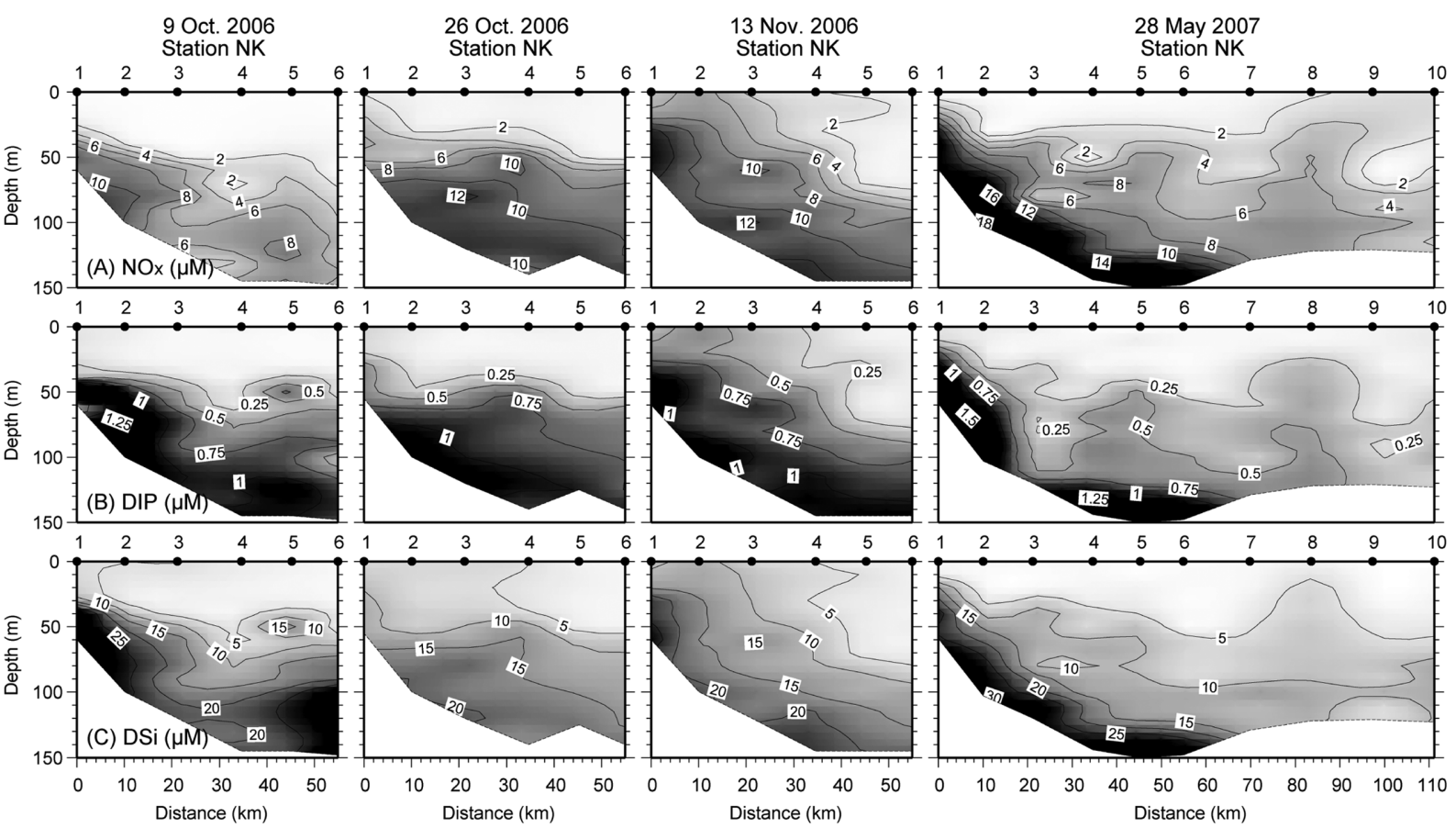

Fig. 4. Contour plots of dissolved inorganic nutrients (A) $\mathrm{NO}_{\mathrm{x}}\left(\mathrm{NO}_{3}^{-}+\mathrm{NO}_{2}^{-}\right)$, (B) DIP, and (C) DSi along the $\mathrm{NK}$ transect in the Korea Strait.

was low compared to May 2007 (Fig. 2). The YangtzeRiver discharge (approximately $9.25 \times 10^{11} \mathrm{~m}^{3} \mathrm{yr}^{-1}$ ) supplies a large amount of fresh water and various materials into the ECS and the Korea Strait (Tian et al. 1993). Surface water runoff, including the discharge of the Nakdong River from the southern coastal region of the Korean peninsula, is another main source of inorganic nutrients in the western channel of the Korea Strait (Lee et al. 1984). However, a narrow range of salinity was observed in November 2006 (33-34.5) compared to October 2006 (3234.5). In November 2006, by destruction of stratified water column, high nutrient concentrations seem to be related to nutrient supply from the subsurface layer to the euphotic zone. On the other hand, lower nutrient concentrations in the euphotic zone associated with a shallow surface mixed layer in May 2007 seem to be caused by nutrient consumption by phytoplankton.

\section{Distribution of phytoplankton community structure}

The dynamic change of water mass properties in the Korea Strait is expected to affect primary producer biomass. As an index of phytoplankton abundance, chlorophyll $a$ concentrations, integrated in the euphotic zone $(<40 \mathrm{~m}$ depth) of the NK transect in the Korea Strait, ranged from 6 to $110 \mathrm{mg} \mathrm{m}^{-2}$ (Fig. 5). Average integrated chlorophyll $a$

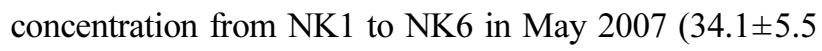

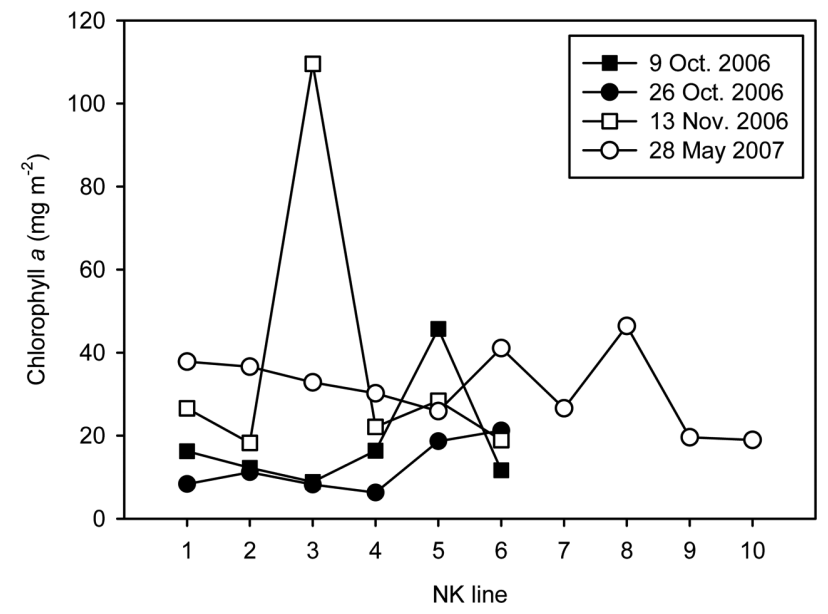

Fig. 5. Distributions of chlorophyll $a$ average inventory $(0-40 \mathrm{~m})$ along the NK transect in the Korea Strait.

$\mathrm{mg} \mathrm{m}^{-2}$ ) was higher than in October $2006(15.4 \pm 10.6 \mathrm{mg}$ $\mathrm{m}^{-2}$ ) by approximately two-fold (Table 2; Fig. 5). Chlorophyll $a$ concentration decreased with increasing offshore bottom water depth in May 2007. The high phytoplankton biomass seems to be related to the expansion of the KSBCW to the euphotic zone on the shelf in May 2007. Although wind-driven coastal upwelling has a different nutrient supply mechanism into the euphotic 
Table 2. Marker pigment concentrations $\left(\mathrm{ng} \mathrm{m}^{-2}\right)$ integrated in the upper $40 \mathrm{~m}$ of each sampling station in the transect of the Korea Strait

\begin{tabular}{|c|c|c|c|c|c|c|c|c|c|c|c|}
\hline Station & Perid & But-fuco & Fuco & Hex-fuco & Pras & Viola & Allo & Lut & Zea & Chl $b$ & Chl $a$ \\
\hline \multicolumn{12}{|c|}{9 Oct. 2006} \\
\hline NK1 & 506 & 27 & 6095 & 339 & 1033 & 108 & 418 & 188 & 1496 & 14739 & 16226 \\
\hline NK2 & 173 & 219 & 3025 & 130 & 1022 & 76 & 213 & 53 & 2322 & 9384 & 12244 \\
\hline NK3 & 267 & 582 & 5637 & 111 & 1561 & 16 & 245 & 11 & 592 & 9040 & 8854 \\
\hline NK4 & 127 & 703 & 13386 & 118 & 2295 & 161 & 460 & 35 & 413 & 9528 & 16391 \\
\hline NK5 & 173 & 515 & 4950 & 236 & 2968 & 75 & 346 & 18 & 1230 & 13927 & 45697 \\
\hline NK6 & 168 & 1088 & 2719 & 803 & 1973 & 37 & 256 & 4 & 950 & 10404 & 11681 \\
\hline \multicolumn{12}{|c|}{26 Oct. 2006} \\
\hline NK1 & 0 & 61 & 2700 & 436 & 171 & 58 & 187 & 72 & 508 & 30514 & 8336 \\
\hline NK2 & 299 & 36 & 4827 & 583 & 361 & 45 & 276 & 35 & 843 & 27054 & 11184 \\
\hline NK3 & 219 & 0 & 2021 & 225 & 147 & 65 & 478 & 530 & 133 & 21472 & 8228 \\
\hline NK4 & 39 & 259 & 1361 & 209 & 615 & 2 & 119 & 3 & 411 & 19742 & 6295 \\
\hline NK5 & 499 & 1048 & 5952 & 4758 & 0 & 133 & 453 & 48 & 1043 & 28023 & 18636 \\
\hline NK6 & 284 & 1231 & 10687 & 57 & 3623 & 8 & 632 & 36 & 528 & 21499 & 21235 \\
\hline \multicolumn{12}{|c|}{13 Nov. 2006} \\
\hline NK1 & 1085 & 8331 & 8223 & 1284 & 2163 & 137 & 636 & 191 & 535 & 18441 & 26558 \\
\hline NK2 & 368 & 204 & 8265 & 340 & 1852 & 100 & 422 & 106 & 399 & 11047 & 18255 \\
\hline NK3 & 845 & 354 & 13184 & 4502 & 950 & 554 & 2135 & 3892 & 267 & 36075 & 109535 \\
\hline NK4 & 715 & 1238 & 5191 & 927 & 5160 & 67 & 535 & 121 & 980 & 14534 & 22089 \\
\hline NK5 & 463 & 713 & 28715 & 61 & 1739 & 0 & 1074 & 2755 & 161 & 4823 & 28410 \\
\hline NK6 & 391 & 546 & 18531 & 12 & 1397 & 0 & 712 & 162 & 104 & 3316 & 18905 \\
\hline \multicolumn{12}{|c|}{28 May 2007} \\
\hline NK1 & 7160 & 472 & 26481 & 1087 & 735 & 1242 & 243 & 62 & 141 & 18551 & 37809 \\
\hline NK2 & 3702 & 481 & 17357 & 1435 & 0 & 610 & 140 & 69 & 17 & 13833 & 36584 \\
\hline NK3 & 11863 & 768 & 9698 & 1404 & 0 & 453 & 8 & 50 & 372 & 9007 & 32844 \\
\hline NK4 & 13779 & 590 & 8894 & 1241 & 0 & 0 & 93 & 236 & 0 & 6201 & 30199 \\
\hline NK5 & 12148 & 359 & 7232 & 866 & 0 & 71 & 62 & 318 & 39 & 6262 & 25906 \\
\hline NK6 & 19271 & 1340 & 14997 & 650 & 973 & 491 & 177 & 253 & 170 & 10496 & 41063 \\
\hline NK7 & 6353 & 920 & 11735 & 3045 & 0 & 229 & 121 & 286 & 112 & 7057 & 26555 \\
\hline NK8 & 11338 & 1160 & 26272 & 3354 & 0 & 65 & 214 & 251 & 27 & 19567 & 46402 \\
\hline NK9 & 2784 & 331 & 7901 & 966 & 13 & 0 & 11 & 373 & 0 & 4174 & 19586 \\
\hline NK10 & 2265 & 450 & 7098 & 1393 & 0 & 9 & 97 & 238 & 0 & 4719 & 18960 \\
\hline
\end{tabular}

${ }^{1}$ Abbreviations of pigment names are listed in Table 1.

zone with the $\mathrm{KSBCW}$, it has frequently occurred in the southeastern part of Korea in summer (Lee and $\mathrm{Na}, 1985$; Kim and Lee, 2004; Yoo and Park, 2009). Yoo and Park (2009) suggested that high primary production in the region is associated with nutrient supply from the subsurface region to the euphotic zone due to coastal upwelling.

Upwelling, induced by a cold eddy, was observed at NK8 in May 2007. Chlorophyll $a$ concentration (46 mg $\mathrm{m}^{-2}$ ) integrated at this station was approximately two-fold higher than at adjacent stations. By supplying nutrients from the subsurface layer to the euphotic zone, this islandinduced eddy has significant impacts on the distribution and productivity of phytoplankton and zooplankton (Morimoto et al. 2009; Onitsuka et al. 2009). The high phytoplankton biomass in the Korea Strait in May 2007 seems be related to the expansion of the KSBCW and the eddy event on the shelf and off the shelf, respectively.

The most abundant diagnostic pigments in the Korea Strait were fucoxanthin and peridinin, indices of diatoms 

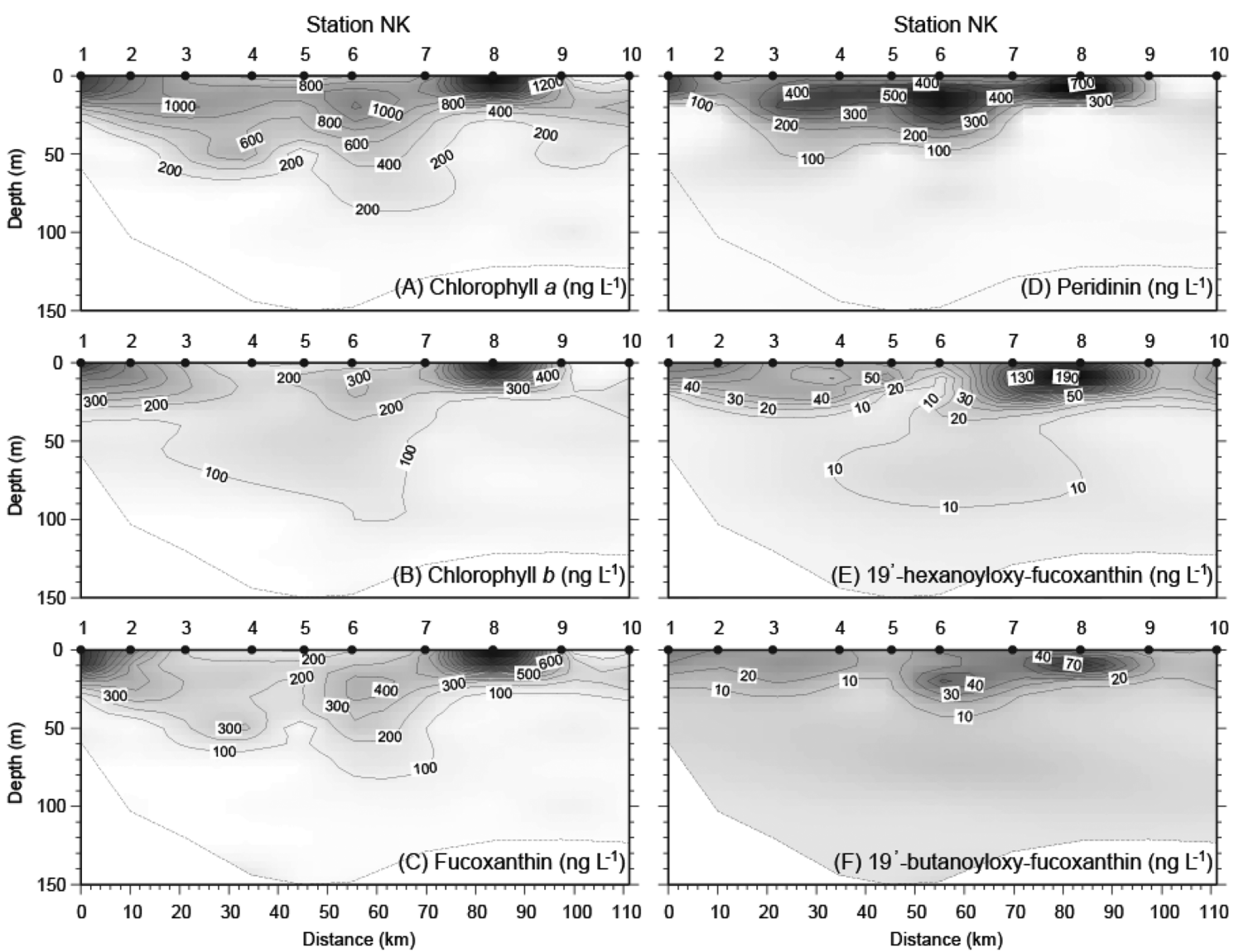

Fig. 6. Contour plots of main marker pigments along the NK transect in the Korea Strait on 28 May 2007.

and dinoflagellates, respectively. In May 2007, fucoxanthin and peridinin, in a transect of the Korea Strait $(<40 \mathrm{~m}$ depth), varied between 69 and $1794 \mathrm{ng}^{-1}$ with a mean of $380 \pm 388 \mathrm{ng}^{-1}$ and between 0 and $848 \mathrm{ng} \mathrm{l}^{-1}$ with a mean of $237 \pm 211 \mathrm{ng} \mathrm{l}^{-1}$, respectively (Table 2). Concentrations of 19'-hexanoyloxy-fucoxanthin, 19'-butanoyloxyfucoxanthin, and prasinoxanthin, indices of small-sized phytoplankton, increased off the shelf as a whole (Fig. 6, Table 2). Diatoms and dinoflagellates in the Korea Strait may flourish when nutrients are supplied from upwelling caused by KSBCW expansion and eddy events, YRDW, and coastal water. However, the relatively lower nutrient conditions off the shelf in the Korea Strait may reduce the growth of larger-sized diatoms or dinoflagellates. Nanoor pico-plankton community may have an advantage off the shelf where nutrient concentrations are low (Furuya et al. 2003).

To understand the temporal and spatial variation of phytoplankton community structure along the NK transect, each marker pigment was integrated in the euphotic zone ( $<40 \mathrm{~m}$ depth). Based on the integrated pigment data, the
CHEMTAX program was used to estimate phytoplankton class-specific contributions to total chlorophyll $a$. Dominant phytoplankton community in the Korea Strait was diatoms and dinoflagellates. Diatoms accounted for approximately $60-70 \%$ of total biomass during the sampling period (Fig. 7), while other phytoplankton groups accounted for less than $40 \%$ at most stations. Dinoflagellates accounted for over $40 \%$ of total biomass between NK3 and NK6 where low silicate concentrations $(<2 \mu \mathrm{M})$ may have limited diatom growth (Egge and Aksnes 1992) (Fig. 7). The dominant phytoplankton community shifted to dinoflagellates, which grew better than diatoms in low silicate conditions. Typically, community changes from largesized phytoplankton to small-sized phytoplankton from the coast to the outer shelf due to nutrient conditions (Furuya et al. 2003). However, in the Korea Strait, other patterns of phytoplankton community structure and biomass were observed in November 2006 and May 2007. Our results suggest that nutrient supply by expansion of the KSBCW and eddies favor the growth of diatoms and dinoflagellates in the Korea Strait. 

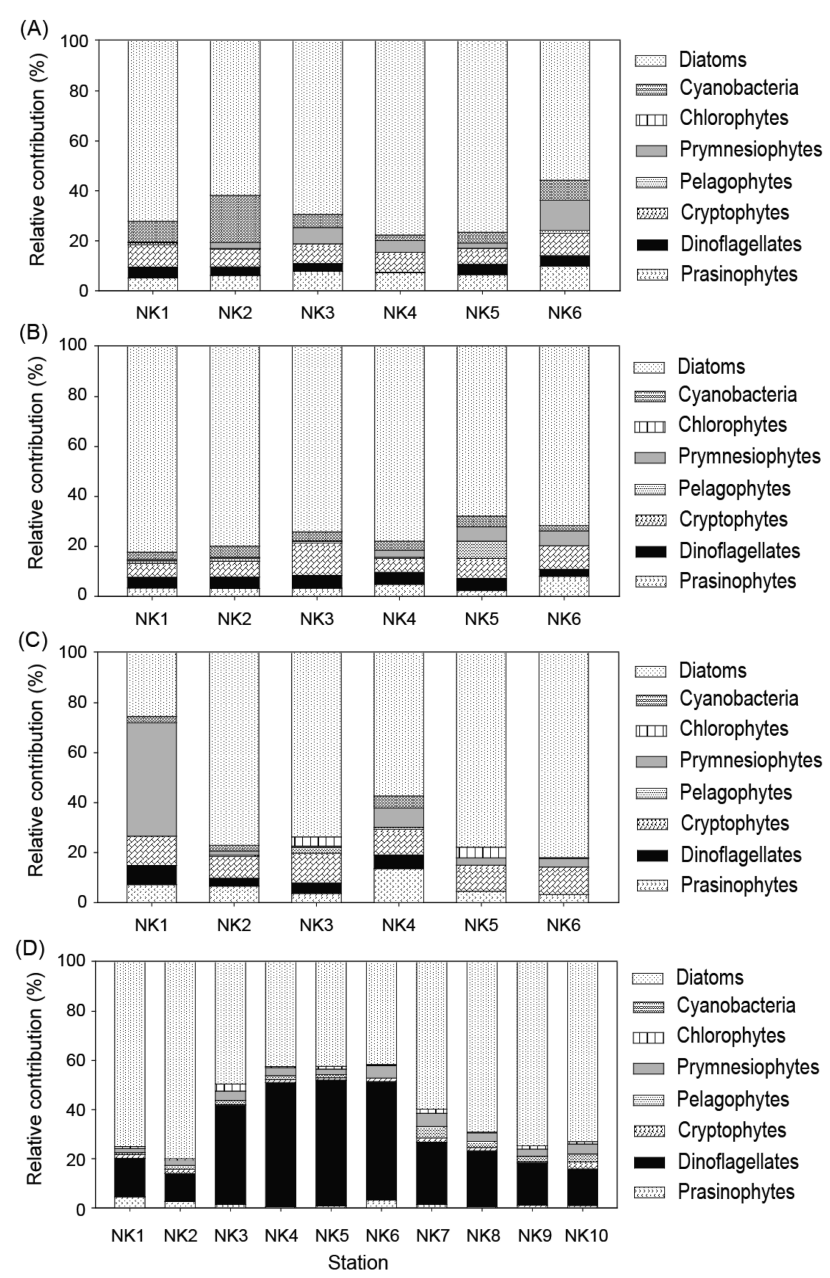

Fig. 7. Distributions of average inventory $(0-40 \mathrm{~m})$ of phytoplankton algal groups on (A) 9 October and (B) 26 October 2006, (C) 13 November 2006, and (D) 28 May 2007 along the NK transect in the Korea Strait.

\section{Acknowledgements}

We would like to thank J. Hwang at POSTECH for providing valuable comments, and C. Kang's Stable Isotope Ecology Lab. members for help with sample collection and laboratory analyses. This work was supported by Korean EAST-I program of the Ministry of Land, Transport, and Maritime Affairs.

\section{References}

Azam F, Fenchel T, Field JG, Gray JS, Meyer-Reil LA, Thingstad F (1983) The ecological role of water-column microbes in the sea. Mar Ecol Prog Ser 10:257-263
Chen YLL, Chen HY (2006) Seasonal dynamics of primary and new production in the northern South China Sea: The significance of river discharge and nutrient advection. Deep-Sea Res 153:971-986

Cho YK, Kim K (1998) Structure of the Korea Strait Bottom Cold Water and its seasonal variation in 1991. Cont Shelf Res 18:791-804

Egge JK, Aksnes DL (1992) Silicate as regulating nutrient in phytoplankton competition. Mar Ecol Prog Ser 83:281-289

Furuya K, Hayashi M, Yabushita Y, Ishikawa A (2003) Phytoplankton dynamics in the East China Sea in spring and summer as revealed by HPLC-derived pigment signatures. Deep-Sea Res II 50:367-387

Gong GC, Chang J, Chiang KP, Hsiung TM, Hung CC, Duan SW, Codispoti LA (2006) Reduction of primary production and changing of nutrient ratio in the East China Sea: Effect of the Three Gorges Dam? Geophys Res Lett 33:L07610. doi:10.1029/2006GL025800

Hassen MB, Drira Z, Hamza A, Ayadi H, Akrout F, Issaoui H (2008) Summer phytoplankton pigments and community composition related to water mass properties in the Gulf of Gabes. Estuar Coast Shelf Sci 77:645-656

Jeffrey SW (1997) Application of pigment methods to oceanography In: Jeffrey SW, Mantoura RFC, Wright SW (eds) Phytoplankton pigments in oceanography: Guidelines to modern methods. UNESCO Publishing, Paris, pp. 457-553

Jiao N, Zhang Y, Zeng Y, Gardner WD, Mishonov AV, Richardson MJ, Hong N, Pan D, Yan XH, Jo YH, Chen CTA, Wang P, Chen Y, Hong H, Bai Y, Chen X, Huang B, Deng H, Shi Y, Yang D (2007) Ecological anomalies in the East China Sea: Impacts of the Three Gorges Dam? Water Res 41:1287-1293

Karl DM (1999) A sea of change: biogeochemical variability in the North Pacific subtropical gyre. Ecosystems 2:181214

Karl DM, Bidigare RR, Letelier RM (2001) Long-term changes in plankton community structure and productivity in the North Pacific Subtropical Gyre: The domain shift hypothesis. Deep-Sea Res II 48:1449-1470

Kim YH, Kim YB, Kim K, Chang KI, Lyu SJ, Cho YK, Teague WJ (2006) Seasonal variation of the Korea Strait Bottom Cold Water and its relation to the bottom current. Geophys Res Lett 33:L24604, doi:10.1029/ 2006GL027625

Kim IN, Lee T (2004) Physicochemical properties and the origin of summer bottom cold waters in the Korea Strait. Ocean Polar Res 26:595-606 
Lee WJ, Cho KD, Choo HS (1984) Chemical characteristics of water types in the Korea Strait. Bull Korean Fish Soc 17:219-229

Lee YW, Lee JM, Kim G (2009) Identifying sharp hydrographical changes in phytoplankton community structure using HPLC pigment signatures in coastal waters along Jeju Island, Korea. Ocean Sci J 44:1-10

Lee JC, Na Y (1985) Structure of upwelling off the southeast coast of Korea. J Oceanol Soc Korea 20:6-19

Lim DB, Chang SD (1969) On the cold water mass in the Korea Strait. J Oceanol Soc Korea 4:71-82

Liu SM, Zhang J, Chen HT, Wu Y, Xiong H, Zhang ZF (2003) Nutrients in the Changjiang and its tributaries. Biogeochemistry 62:1-18

Lyu SJ, Kim K, Perkins HT (2002) Atmospheric pressureforced subinertial variations in the transport through the Korea Strait. Geophys Res Lett 29:1294, doi:10.1029/ 2001GL014366

Mackey MD, Mackey DJ, Higgins HW, Wright SW (1996) CHEMTAX - a program for estimating class abundances from chemical markers: application to HPLC measurements of phytoplankton. Mar Ecol Prog Ser 144:265-283

Moline MA (1998) Photoadaptive response during the development of a coastal Antarctic diatom bloom and relationship to water column stability. Limnol Oceanogr 43:146-153

Morimoto A, Takikawa T, Onitsuka G, Watanabe A, Moku M, Yanagi T (2009) Seasonal variation of horizontal material transport through the eastern channel of the Tsushima Straits. J Oceanogr 65:61-71

Onitsuka G, Morimoto A, Takikawa T, Watanabe A, Moku M, Yoshikawa Y, Yanagi T (2009) Enhanced chlorophyll associated with island-induced cyclonic eddies in the eastern channel of the Tsushima Straits. Estuar Coast Shelf Sci 81:401-408

Onitsuka G, Yanagi T, Yoon JH (2007) A numerical study on nutrient sources in the surface layer of the Japan Sea using a coupled physical-ecosystem model. J Geophys Res 112:C05042, doi:10.1029/2006JC003981

Reid PC, Lancelot C, Gieskes WWC, Hagmeier E, Weichart G (1990) Phytoplankton of the North Sea and its dynamics: a review. Neth J Sea Res 26:295-331

Ruardij P, van Haren H, Ridderinkhof H (1997) The impact of thermal stratification on phytoplankton and nutrient dynamics in shelf seas: a model study. J Sea Res 38:311-331

Schofield O, Prézelin BB, Bidigare RR, Smith RC (1993) In situ photosynthetic quantum yield. Correspondence to hydrographic and optical variability within the Southern California Bight. Mar Ecol Prog Ser 93:25-37

Takikawa T, Yoon JH, Cho KD (2005) The Tsushima Warm Current through Tsushima Straits estimated from ferryboat ADCP data. J Phys Oceanog 35:1154-1168

Tian RC, Hu FX, Martin JM (1993) Summer nutrient fronts in the Changjiang (Yantze River) Estuary. Estuar Coast Shelf Sci 37:27-41

Wright SW, Jeffrey SW, Mantoura RFC, Llewellyn CA, Bjørnland T, Repeta D, Welschmeyer N (1991) Improved HPLC method for the analysis of chlorophylls and carotenoids from marine phytoplankton. Mar Ecol Prog Ser 77:183-196

Yanagi T (2002) Water, salt, phosphorus and nitrogen budgets of the Japan Sea. J Oceanogr 58:797-804

Yang JS, Choi HY, Jeong HJ, Jeong JY, Park JK (2000) The outbreak of red tides in the coastal waters off Kohung, Chonnam, Korea: 1. Physical and chemical characteristics in 1997. J Korean Soc Oceanogr 5:16-26

Yoo S, Park J (2009) Why is the southwest the most productive region of the East Sea/Sea of Japan? J Mar Sys 78:301-315 